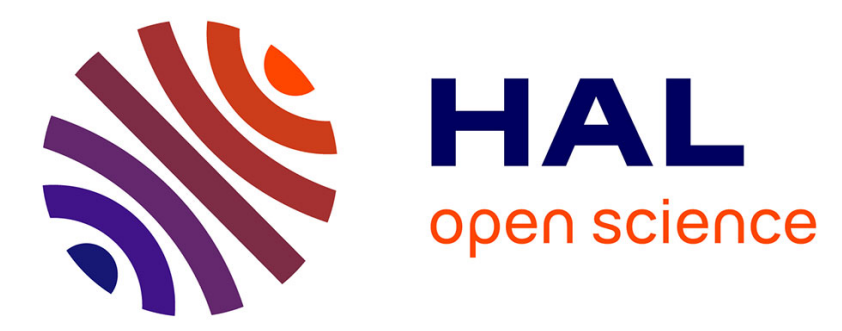

\title{
Acoustic detection of nanoparticle structural stability in physiological media after their laser irradiation
}

\author{
I. Zelepukin, A. Popov, A. Kabashin, S. Deyev, A. Zvyagin
}

\section{To cite this version:}

I. Zelepukin, A. Popov, A. Kabashin, S. Deyev, A. Zvyagin. Acoustic detection of nanoparticle structural stability in physiological media after their laser irradiation. 2020 International Conference Laser Optics (ICLO), Nov 2020, Saint Petersburg, France. pp.1-1, 10.1109/ICLO48556.2020.9285450 . hal-03456829

\section{HAL Id: hal-03456829 \\ https://hal.science/hal-03456829}

Submitted on 30 Nov 2021

HAL is a multi-disciplinary open access archive for the deposit and dissemination of scientific research documents, whether they are published or not. The documents may come from teaching and research institutions in France or abroad, or from public or private research centers.
L'archive ouverte pluridisciplinaire HAL, est destinée au dépôt et à la diffusion de documents scientifiques de niveau recherche, publiés ou non, émanant des établissements d'enseignement et de recherche français ou étrangers, des laboratoires publics ou privés. 


\title{
Acoustic detection of nanoparticle structural stability in physiological media after their laser irradiation
}

\author{
I.V. Zelepukin ${ }^{1,2 *}$, A.A. Popov ${ }^{1}$, A.V. Kabashin ${ }^{1,3}$, S.M. Deyev ${ }^{1,2}$, A.V. Zvyagin ${ }^{1,4,5}$ \\ ${ }^{1}$ National Research Nuclear University MEPhI, Russia \\ ${ }^{2}$ Shemyakin-Ovchinnikov Institute of Bioorganic Chemistry RAS, Russia \\ ${ }^{3}$ Aix Marseille Univ, CNRS, LP3, Campus de Luminy, France \\ ${ }^{4}$ I.M. Sechenov First Moscow State Medical University, Russia \\ ${ }^{5}$ ARC Centre of Excellence for Nanoscale BioPhotonics, Macquarie University, Australia \\ *Presenting author e-mail address: zelepukin@phystech.edu
}

\begin{abstract}
Here we present a method of photoacoustic detection of nanoparticle degradation. To validate the method, we used biodegradable silicium nanoparticles, which can absorb light in the $\mathrm{Uv}-\mathrm{V}$ is region and generate acoustic waves in response. The photoacoustic method allows measuring kinetic of their degradation in real-time with high limit of detection up to a hundred ng of particles.
\end{abstract}

Keywords - nanoparticles; photoacoustics; laser ablation; degradation.

\section{INTRODUCTION}

Novel methods for non-invasive imaging and quantifying of various biological processes are under development nowadays [1-5]. Although a lot of optical techniques were designed for investigation of nanoparticle pharmacokinetics and distribution, they usually have limitations for measuring long-term processes. For example, biodegradation and excretion of luminescent nanomaterials can't be precisely quantified due to the sharp decrease of their brightness during nanocrystal deformation.

Contrary, photoacoustic detection [1] can be a promising platform for imaging of long-term fate of luminescent contrast agents, as well as any absorbing light nanomaterials. That approach detects acoustics waves, which generates in the response to nanomaterials heating after their irradiation with a pulsed laser. The method can almost in real-time, quantitatively detect small amounts of "black" (by their spectra) nanomaterials in vivo, and spectrally distinguishes the signal from nanoagents from background noise.

Here we applied the photoacoustic method to measure complex kinetics of silicon nanoparticle degradation in various buffer solutions.

\section{RESUltS AND DisCUSSION}

Photoacoustic detection of structural changes in nanoparticles can be possible due to high decrease in the absorbance spectra or volume of nanomaterials during the process of their degradation, which significantly lower acoustic waves generation.

To validate optoacoustic technique for that aim we used pure silicon nanoparticles, a material with a known ability to biodegradation in vivo [6]. These nanoparticles can be

The work was supported by the grants of the Russian Science Foundation № 19-72-30012 (nanoparticle synthesis) and Russian Foundation for Basic Research № 19-29-04012 (detection technique). dissolved due to nanocrystal water hydrolysis and ion exchange with the release of silane acids.

Silicon particles were prepared by the femtosecond laser ablation method and show high absorbance at the Uv-Vis region after the synthesis. Structure, composition and colloid-chemical properties of the nanocarriers were investigated by scanning electron microscopy, Fourier transform infrared spectroscopy and dynamic light scattering technique.

Laser irradiation of silicon nanoparticles at $532 \mathrm{~nm}$ led to a strong photoacoustic signal from them. It allowed us to measure the kinetics of their degradation at different $\mathrm{pH}$, particle composition and concentrations in solutions. We found that $\mathrm{pH}$ in media is the most important parameter and its tuning allows accelerate nanoparticle full degradation time from several weeks to 1 day.

\section{CONCLUSSION}

Our results demonstrate applicability of photoacoustic for quantitative detection of structural stability of silicon nanoparticles. Potentially, photoacoustic technology can be translated for in vivo study of the long-term fate of a wide range of light absorbing nanoagents.

\section{REFERENCES}

[1] Weber, J., Beard, P. C., \& Bohndiek, S. E. “Contrast agents for molecular photoacoustic imaging”, Nature methods, vol. 13(8), pp. 639-650, 2016.

[2] Kabashin, A. V., Kravets, V. G., Wu, F., Imaizumi, S., Shipunova, V. O., Deyev, S. M., \& Grigorenko, A. N. "Phase-Responsive Fourier Nanotransducers for Probing 2D Materials and Functional Interfaces", Advanced Functional Materials, vol. 29(26), p 1902692, 2019.

[3] Zelepukin, I. V., Yaremenko, A. V., Shipunova, V. O., Babenyshev, A. V., Balalaeva, I. V., Nikitin, P. I., Deyev, S. M. \& Nikitin, M. P. "Nanoparticle-based drug delivery via RBC-hitchhiking for the inhibition of lung metastases growth", Nanoscale, vol. 11(4), pp. 1636-1646, 2019.

[4] Shevchenko, K. G., Cherkasov, V. R., Nikitina, I. L., Babenyshev, A. V., \& Nikitin, M. P. "Smart multifunctional nanoagents for in situ monitoring of small molecules with a switchable affinity towards biomedical targets", Applied Nanoscience, vol. 8(1-2), pp. 195-203, 2018.

[5] Zelepukin, I. V., Yaremenko, A. V., Petersen, E. V., Deyev, S. M., Cherkasov, V. R., Nikitin, P. I., \& Nikitin, M. P. "Magnetometry based method for investigation of nanoparticle clearance from circulation in a liver perfusion model", Nanotechnology, vol. 30(10), p. 105101, 2019.

[6] Petriev, V. M., Tischenko, V. K., Mikhailovskaya, et.al. "Nuclear nanomedicine using Si nanoparticles as safe and effective carriers of 188 Re radionuclide for cancer therapy", Scientific reports, vol. 9(1), pp. 1$10,2019$. 